\title{
Botswana development vision and localisation of UN Sustainable Development Goals
}

\section{Commonwealth Journal of Local Governance}

Issue 20: December 2017

https://cjlg.epress.lib.uts.edu.au

\section{Norbert Musekiwa}

Department of Political and Administrative Studies

University of Botswana

Botswana

Email: norbert.musekiwa@mopipi.ub.bw norbert.musekiwa@gmail.com

\section{David Mandiyanike}

Department of Political and Administrative Studies University of Botswana

Botswana

Email: david.mandiyanike@mopipi.ub.bw mandiyaniked@gmail.com
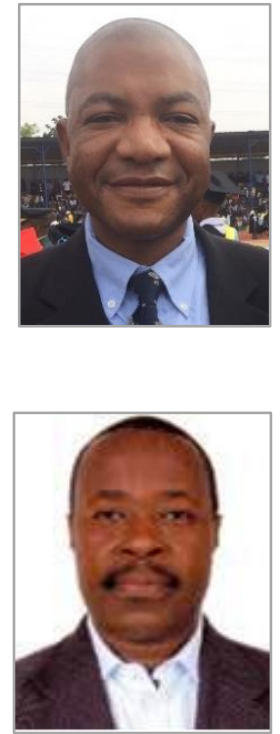

\begin{abstract}
This paper considers how the Botswana government could use the experiences of implementing the UN Millennium Development Goals (MDGs) to localise their successor Sustainable Development Goals (SDGs) in the country's new development strategy Vision 2036. Despite the recentralisation of some elements of service delivery (water, education, and health) reversing the decentralisation trend, Botswana attained respectable successes in achieving MDG targets. The localisation of development goals must however go beyond simply establishing effective and efficient decentralised local government units, to implementing local economic development strategies that enable communities to take an active role in national development processes. The primary question that this discussion paper seeks to answer is: can Botswana utilise lessons learnt in implementing the MDGs to the SDGs, to foster an empowered local community? The paper highlights how community empowerment is particularly critical in Botswana; on the one hand given the current over-dependence of the economy on a limited number of extractive, finite mineral resources, and on the other because of the multi-dimensional character of poverty and high income inequality afflicting Botswanans. The call for greater decentralisation in Botswana's Vision 2036 provides a good example for the Commonwealth as it goes beyond the SDGs' target date of 2030.
\end{abstract}

Keywords: Botswana, Millennium Development Goals, Sustainable Development Goals, Vision 2036

DOI: https://doi.org/10.5130/cjlg.v0i20.6469

Article History: Received 05/06/2016; Accepted 12/04/18; Published 13/03/2019

Citation: Commonwealth Journal of Local Governance 2017, 20: 6469, - https://doi.org/10.5130/cjlg.v0i20.6469

(c) 2019 Norbert Musekiwa and David Mandiyanike. This is an Open Access article distributed under the terms of the Creative Commons Attribution 4.0 Unported (CC BY 4.0) License (https://creativecommons.org/licenses/by/4.0/), allowing third parties to copy and redistribute the material in any medium or format and to remix, transform, and build upon the material for any purpose, even commercially, provided the original work is properly cited and states its license. 


\section{Introduction}

Botswana has achieved remarkable socio-economic progress since its attainment of independence in 1966 (World Bank 2014). It moved from the ranks of being one of the poorest countries in the world to upper middle-income status (World Bank 2017) with "annual real GDP growth averaging nine percent a year from 1966 to 2008" (United Nations Development Programme 2010, p. 11) and made significant progress in the attainment of Millennium Development Goals (MDGs). The United Nations Development Programme (UNDP) final report on MDGs (2015a) indicates that Botswana achieved all targets ${ }^{1}$ under MDGs 1, 2, 4 and 6 on eradicating extreme poverty and hunger, universal primary education, reduction in child mortality, and on combating HIV/AIDS, malaria and other diseases respectively (UNDP 2015b). This includes more than halving the proportion of people living below the poverty line from $47 \%$ in 1993 to $19 \%$ by 2010 - five years ahead of the target date (UNDP 2015a). There was one significant reversal in target 6 of MDG 5 to improve maternal health highlighting underinvestment in the health sector. These impressive statistics show that between 2003 and 2010, the country has in many ways consistently proved a development success (UNDP 2015c; Lekalake 2016).

For long-term sustainable development to occur however, a capacitated local citizenry is required, able to engage in their own development activities without excessive oversight from the centre, and with local communities allowed to determine their own development agenda as much as possible. Botswana's new long-term development strategy, Vision 2036, (2016, p. 27) acknowledges that decentralisation promotes participatory development, and local-level institutions are important vehicles of bottom-up development planning and community-driven development. Until now, however, central government has been in charge of all major development activities in Botswana, leaving local communities and local authorities as spectators in their own development, meaning that if central government were to withdraw from the development process, these centre-driven initiatives would risk grinding to a halt. This is despite the acknowledgment in the Vision 2036 text that capacitated local communities and local authorities with some degree of autonomy can spearhead their own development processes.

This paper argues that internally generated capacity-building efforts are more sustainable than a topdown approach, whose effects typically fade once the external funding is withdrawn or reduced. In decentralisation thinking, the subsidiarity principle means government must devolve responsibilities to local authorities in those areas where local delivery of service makes it easier to ensure no one is left behind. In Botswana, this typically occurs under circumstances where the central government is under social, political or economic pressure to devolve substantial subventions to local authorities. In other cases, there has been an organised 'wean off' of services to local authorities, where central government has devolved powers when local authorities are considered mature enough to take on the responsibilities.

\footnotetext{
${ }^{1}$ UNDP (2015a) also highlights where Botswana was slow in attaining MDG 3, target 4 on ensuring gender equality, Goal7, target 10 ensuring environmental sustainability and Goal 11 on development of partnerships for development.
} 
Botswana was one of the first countries in Africa to assess its progress against the MDGs and released its first status report in 2004 (UNDP 2010). The 2010 progress report, the second for Botswana, bears testimony to the Government of Botswana's continued commitment to the MDGs (UNDP 2010). The government's Vision 2016 long-term strategy adopted in 1996 guides the national development agenda to achieve a competitive and prosperous nation. Botswana has now rolled out the second long-term strategy: Vision 2036 - which will take the country up to its 70th independence anniversary. Botswana's strategy provides interesting insights as it goes beyond 2030, to 2036. As noted by Sharma (2010), Botswana has over the years cultivated a conducive and enabling democratic political environment in which local government can develop, and such national visions are critical in guiding the operations of local authorities, as for example stated by the Local Government Association of Tasmania in its 2006 Local government sustainability, Discussion Paper as such documents are "important that local government understands where it is going and what it wants over the coming few decades" (p. 1).

This paper starts by setting the context for local government in Botswana: the inherent challenges and how Vision 2016 has fared. These are then reviewed against the new Vision 2036 and a conclusion and lessons for the future are drawn. The paper draws on a critical literature review, archival records, legislation, and media reports. Botswana government review reports on MDGs and national development plans were particularly relevant. Additional data was derived from key informant interviews in what Stroh (2000) calls "conversations with a purpose". Six key informant interviews were held from April to August 2015 and respondents were purposefully selected from the Botswana UNDP office, Ministry of Local Government, Botswana Local Government Association (BALA) and National Strategy Office (NSO).

\section{An overview of local government in Botswana}

Botswana has a long history of democratic practice pre-dating political independence and modern local government in Botswana builds directly on pre-colonial institutions, especially in relation to the internal organisation of tribes under the stewardship of tribal councils (Sharma 2010; Dipholo et al. 2011). These tribal councils, established during the protectorate era, performed limited local government functions such as identification and implementation of community projects.

Local government in Botswana stands on four pillars: (a) councils (city councils, town councils, district councils, and sub-district councils); (b) district administration, headed by district commissioners; (c) land boards, created after independence for managing the allocation of tribal land; and (d) tribal administration, headed by chiefs as traditional leaders (Sharma 2010 and Dipholo et al. 2011; see also Wright 2015). District administration in Botswana, however, is more of a deconcentrated administrative arrangement than local government and public administration in the strict sense (Hope 2000). However, district administration has a dominant role in the devolved structures, especially in project coordination and management at the district level (Hope 2000). 
The district and urban councils, established by the Local Government (District Councils) Act 2012 (Chapter 40.01) and the Township Act 2012 (Chapter 40.02) respectively, have statutory responsibility for, among other functions, primary healthcare, primary education, and rural village water supply (Dipholo et al. 2011). In law therefore, local governments in Botswana enjoy autonomy in the delivery of a wide range of services. Thanks to their developmental responsibilities, councils constitute a pivotal institution of local government, making them the most recognised organ of local government. However, as will be argued later, the practice in local governments in reality involves significant direction by central government, limiting council autonomy.

The Government of Botswana through collaboration with the Commonwealth Local Government Forum (CLGF) is making concerted efforts to improve its present patchy decentralisation, as evidenced by the current work on a new decentralisation policy. The specific objectives of this are to: a) empower local governments as key drivers of good governance, sustainable and responsive service delivery and local development; b) improve the administrative and human resource capacity of local governments, line ministries and other actors at the local level to ensure quality service delivery; c) enhance effective, efficient and accountable planning, implementation and monitoring capacity in service delivery at the local level; d) strengthen accountability and transparency of national and local leaders and institutions, including non-state actors to the communities that they serve; and e) enhance the responsiveness of planning, financing, management, and control of service delivery and local development processes by all sectors to local needs.

\section{Botswana development performance so far}

As Botswana looks to the post-2015 development agenda and winds up its Vision 2016, it is informative to assess the achievements over the last decade or two. Botswana made remarkable progress in almost all MDGs, achieving or nearly achieving the targets for MDGs 1, 2, 3, 6, 7 and 8. There was also significant progress on the other MDGs, as a result of sustained investment in socio-economic development; however, Botswana missed targets for the reduction in under-five and infant mortality (MDG 4) and maternal mortality (MDG 5) (Lekalake 2016; UNDP 2015a; UNDP 2013).

The government's Vision 2016 featured sustained investment in socio-economic development. It is therefore important to note that further investment in infrastructure and poverty reduction strategies may not necessarily lead to further declines in maternal mortality (Government of Botswana 1996, p. 21), although commendable progress against the Vision 2016 objectives has been noted (Lekalake 2016). Chiepe (2014) highlighted several successes: that poverty reduced from $47 \%$ in 1993 to $28 \%$ in 2005 , the adult literacy rate had risen to $84 \%$ in 2012 , and there were high enrolment rates in both primary and secondary schools. However, despite this considerable progress there remain significant challenges. This paper argues the need for the deeper involvement of local governments and local 
communities in formulating and implementing Botswana's strategic vision, and in the next section we look at some of the key challenges identified within the Botswana local government framework.

\section{Challenges for local government in Botswana}

Botswana's legal framework poses a number of challenges for effective local government. Local government institutions derive their legitimacy and power to function from statutes or administrative directives and have no constitutionally derived or protected competence (Dipholo et al. 2011; see also Poteete et al. 2014; Hope 2000). As creatures of Acts of Parliament, therefore, local governments could be abolished any time at the discretion of the legislature. This vulnerability ensures that local governments' spheres of operation continue to be prescribed by central government and could be changed: either by expanding or contracting their mandates, and/or by increasing or decreasing financial and administrative support. Local government institutions therefore continue to rely on central government for their operations and sustenance, with the result that they are simply seen as an extension of the central government responsible for implementation of projects at the local level. Indeed, the Ministry of Local Government website notes that its mandate is primarily to "oversee sixteen subsidiary semi-autonomous local authorities that facilitate develop programmes at the local level" (Ministry of Local Government 2017, p. 1). This exposes local government to the whims of the centre, which retains the right to recall delegated functions. This is not just a hypothetical risk and in 2010 central government unilaterally took over education and health functions from local governments (Dipholo et al. 2011).

Limited access to sources of income causes local governments to operate merely as deconcentrated agencies of the Ministry of Local Government. Councils do not have significant independent sources of revenue, so the vast majority of development expenditure is met by central government: $97 \%$ of the recurrent expenditure of rural councils and about $80 \%$ of that of urban councils (Sharma 2010, p. 137). A further problem is that these fiscal transfers to local authorities are determined on an annual basis, effectively stifling long-term planning by the recipient institutions. In light of these realities, Dipholo and Mothusi (2005) have argued that the government does not seem to support its own efforts towards decentralisation beyond mundane talk of capacity-building, and has in fact adopted an over-cautious approach towards decentralisation.

Local government's lack of own source funding and dependency on central government neutralises its ability to be in charge of its own development. This problem is compounded by high default rates and arrears on service charges, unpaid property rates owed to the urban councils, and ineffectiveness in rate and service charge collection, among other challenges, which impede local government self-funding. Additionally, the revenue sources for district councils are significantly lower than those of urban councils (Sharma 2010), resulting from rural areas being relatively poorer in comparison to urban areas. Sharma advises that local authorities need to reduce their heavy dependence on central government finance and develop their own independent sources of revenue to be able to break the cycle. Also, as is constitutionally mandated in Nigeria, Kenya and elsewhere, central government should work out a formula for sharing 
the revenue from national resources extraction with the local council. Reflecting the present subordinate position, in Botswana the local government sector was not formally included in the original MDG formulation in 2000 (Amis 2013), which was instead a preserve of central government (Slack 2014).

While Vision 2016 has yet to be fully evaluated, the government has identified further challenges. Conversations with the National Strategy Office highlighted that while the Botswana per capita income brings it to the group of middle-income countries, the development challenges that Batswana are facing are not very different from those common to low-income countries (interview with NSO officer 2015). In particular, the average level of income masks a highly unequal income distribution, which compromises the poverty reduction impact of income growth, leaving nearly one-fifth of citizens below the poverty line. Botswana's economic growth model is also unsustainable, being dominated by diamond mining and public sector spending; and this dependence of the economy on a finite resource renders it vulnerable to global price fluctuations and unpredictable financial stresses and crises. It is noteworthy that no non-diamond sector has emerged as a pillar of future growth with strong global competitiveness, and that the private sector continues to be highly dependent on government spending (Vision 2036, 2016). Several other problems compound the country's difficulties. Economic growth has long been affected by low productivity and has been declining in recent years. Human development outcomes have also fallen below expectations, in spite of continuous government investment in health and education; while efforts to address Botswana's development challenges continue to be hampered by implementation bottlenecks resulting from a lack of effectiveness and efficiency of the public sector (Vision 2036, 2016).

In preparing its new Vision 2036, Botswana, like in so many other African and Commonwealth countries, has brought together policies, strategies and programmes which have been planned by a plethora of fragmented and isolated departments and agencies/field administrations which operate in local government spaces but remain organically linked and accountable to line ministries at the centre. This, we argue, results in sub-optimal development outcomes. This paper further argues that this suboptimisation is exacerbated because departments and agencies try to outdo each other in a bid to assert themselves and their importance. The reality is that policies, institutions and frameworks have been developed and implemented by line ministries, departments, state enterprises and parastatals without due regard to local development realities and opportunities, and with only limited participation of local institutions and local actors (interviews with Ministry of Local Government officials 2015). This in turn restricts participation at the lowest levels of governance, whose communities are nevertheless the major consumers of these policies. At the same time, government welfare projects such as Botswana's public works (ipelegeng) programme and economic stimulus packages, which are conceived and delivered by central government, undermine the capacity of local authorities to independently formulate and implement development programmes. 


\section{What could to be done?}

An engaged and informed citizenry is a cornerstone of sound local governance. The authors suggest that the following key elements should be included in Botswana's strategic long-term vision: draw from and reinforce the explicit recognition of local government as primary stakeholders highlighted in Vision 2036 (p. 27); capacity-building to enable local governments to deliver on their mandated responsibilities; and capacity-building among local citizens and civil society to enable them to hold their local government accountable (Satterthwaite and Mitlin 2013; and Amis 2013).

The outcomes of the UN's 'high-level global dialogue' on its consultation paper 'Localizing the Post2015 Development Agenda' included the following finding:

Local and Regional Governments (LRGs) are essential for promoting inclusive sustainable development within their territories and, therefore, are necessary partners in the implementation of the Post-2015 agenda: effective local governance can ensure the inclusion of a diversity of local stakeholders, thereby creating broad-based ownership, commitment and accountability; an integrated multi-level and multi-stakeholder approach is needed to promote transformative agendas at the local level, and; strong national commitment to provide adequate legal frameworks and institutional and financial capacity to local and regional governments is required (UNDP 2014, p. 12).

Decentralisation on the one hand takes services closer to the people, and on the other enables their voices to be heard, through local-level political representation (Vision 2036, 2016). However, decentralisation cannot be effective if it stops at the district level; it must be taken further down, to the town and village level (Sharma 2010). However, Sharma also cautions that the mindset about village development committees has to change, to encourage people's participation in local-level governance. Another key issue, as identified by Wright (2015) in his evaluation was that as well as 'localising' the SDGs, it is essential to 'localise the resources', so that local government has the necessary financial and technical capacity to implement the development goals. In principle, this is an objective of Vision 2036 which commits that the decentralisation of power, decision-making, resource mobilisation and service delivery will underpin the Botswana governance system.

\section{Conversations with Batswana policymakers}

The consultation with policymakers from the Ministry of Local Government, Botswana Local Government Association (BALA) and National Strategy Office and Botswana UNDP office focused on the following three questions:

- Have you actively taken the MDGs into account in local consultations, planning and service delivery?

- What are the key challenges that you see which would affect local government playing a full role in implementing the SDGs and how could they be overcome to successfully localise the SDGs?

- How can we improve coordination between local, provincial/state and national government to ensure successful implementation of the SDGs post-2015? 
The above issues were also included in ongoing discussion about local economic development (LED) frameworks with an official from the Ministry of Local Government, who referred to a draft LED framework and action plan for Botswana (Government of Botswana 2014). The interviewed officials indicated that the draft action plan acknowledges that the efficacy of any serious LED effort depends on, and should be driven by, a combination of three elements: a decentralised governance system; empowered local governments; and empowered communities/ institutions/ actors. In addition, its success and impact are also dependent on national stakeholder participation and cohesion i.e. the buyin and commitment of leadership at all levels.

The 2015 UNDP Botswana status report (2015a) agrees, arguing that to be effective national policies, institutions and planning frameworks have to be informed by localised and context-specific responses to the identified challenges. This notion of 'localising' national development lies at the core of the draft LED framework for the country. The report further adds that LED processes need to entail: (a) building capacity to respond to national development challenges at local levels; (b) facilitating local governments, local institutions and actors including communities to get together to analyse their economies, identify their needs, and mobilise both local and external resources; and (c) creating partnerships that take joint action to stimulate economic growth, increase jobs, incomes and taxes, and in the process eradicate poverty and inequality.

\section{Provision for the new long-term strategic vision}

As discussed above, as Vision 2016 came to an end, efforts were intensified to come up with another long-term vision. These efforts included consultations with stakeholders, and the taskforce team travelled the breadth and length of the country addressing kgotla $^{2}$ meetings and holding focus group discussions (Vision 2036, preamble 2016, p. viii). The National Strategy Office saw this as an opportune moment for review, reflection and reorientation, with a sense of urgency about the future of the country and shared aspirations and dreams for the future. The task team in its report noted that it had listened carefully and with admiration as citizens responded eloquently and passionately about the future Botswana they would like to see and live in by 2036.

Another UNDP report (2015b) expresses hope that the 'localisation' of national development can also be achieved through the establishment of sustainable and effective partnerships between central government, empowered local institutions, communities and non-state actors. The report cites the need for concerted efforts on a bottom-up approach that empowers local governments, local institutions and communities, and deepens civic and private sector participation in sustainable service delivery.

\footnotetext{
${ }^{2}$ A Botswana-specific traditional system of participation by all adults in the village, see CLGF 2017.
} 


\section{Conclusion}

An informed and engaged citizenry is an essential condition for sustainable development. However, to ensure stakeholders' participation in policy development, there is a need for the development of sustainable reciprocal relationships between central and local government and between local government and citizens. Meaningful democratic local governance transcends mere service delivery and places greater emphasis on local institutions and structures that facilitate people's active participation in making decisions about their development so as to reflect people's needs and priorities. Strong and effective local institutions and structures are also needed ensure that even if central government decided to stifle local government, local people would remain organised and visible.

Local governments form a vital bridge between national governments and communities/citizens and have a critical role in that partnership. The effort towards a revitalised decentralisation policy provides a clear window of opportunity to incorporate all the issues people have raised on the local government they need. For example, strengthening local governments by increasing their financial support and autonomy would go a long way to confirm local governments as key participants in the development process.

Botswana's Vision 2036 comes into operation at the same time as the new SDGs and there is need for concerted efforts to raise community participation and involvement if these visions are to be realised. A strong local government voice will also be essential if local government's place within the implementation framework for the SDGs is to be secured - in line with the international consensus that many of the key services essential to meeting the proposed SDGs must be delivered at the local level, as local councils are in the best position to ensure that the needs of local people are understood and met, and that the SDGs 'leave no one behind'.

\section{Declaration of conflicting interest}

The authors declared no potential conflicts of interest with respect to the research, authorship, and/or publication of this article.

\section{Funding}

The authors received no financial support for the research, authorship, and/or publication of this article.

\section{References}

Amis, P. (2013) Local government: How does it fit into the post 2015 MDG agenda? Commonwealth Journal of Local Governance, (13/14), 4-16.

Chiepe, G.K. (2014) Remarks by Dr Gaositwe K.T. Chiepe at the Vision 2016 awards ceremony, held at Gaborone International Convention Centre at 8.00 p.m. Gaborone.

Commonwealth Local Government Forum. (CLGF) (2017) The local government system in Botswana. In Commonwealth Local Government Handbook 2017/18. London: Commonwealth Local government Forum. Available at: www.clgf.org.uk/botswana 
Dipholo, K.B., Mafema, E.D. and Tshishonga, N. (2011) Challenges and opportunities of democratic decentralisation in sustaining local government in Botswana and South Africa. Journal of Public Administration, 46 (4), 1431-1444.

Dipholo, K. and Mothusi, B (2005) Decentralization in Botswana: The reluctant process. Journal of Social Development in Africa, 20 (1), 40-58. https://doi.org/10.4314/jsda.v20i1.23893

Government of Botswana. (1996) Vision 2016. Gaborone: Government of Botswana.

Government of Botswana. (2012a) Local Government Act (Chapter 40.01). Gaborone: Government of Botswana.

Government of Botswana. (2012b) Township Act (Chapter 40.02). Gaborone: Government of Botswana

Government of Botswana. (2014) Draft LED framework and action plan for Botswana. Gaborone: Government of Botswana.

Hope, K.R. (2000) Decentralization and local governance theory and the practice in Botswana. Development Southern Africa, 17 (4), 519-534. https://doi.org/10.1080/03768350050173912

Lekalake, R. (2016) Evaluating Botswana's performance on National Vision 2016. Public opinion on development pillars. Afrobarometer Policy Paper No. 33. Available at: http://afrobarometer.org/sites/default/files/publications/Policy\%20papers/ab_r6_policypaperno33.pdf

Local Government Association of Tasmania. (2006) Local government sustainability, Discussion Paper. Hobart: Local Government Association of Tasmania.

Ministry of Local Government. (2017) About MLG: Mandate. Gaborone. Available at: www.gov.bw/en/Ministries--Authorities/Ministries/Ministry-of-Local-Government-MLG1 [Accessed 21 June 2017].

Poteete, A.R., Mothusi, B. and Molaodi, D. (2014) Decentralization in Botswana: Political and economic obstacles to democratic decentralization. In: Dickovick, J.T and Wunsch, J. (eds.) Decentralization in Africa: The paradox of state strength, Chapter: 2 (pp. 23-43). Boulder, Colorado: Lynne Rienner Publishers.

Satterthwaite, D. and Mitlin, D. (2013) A future that low-income urban dwellers want, and can help secure. Human Settlement Working Paper series Poverty Reduction in Urban Areas 38. London: International Institute for Environment and Development.

Sharma, K. (2010) Role of local government in Botswana for effective service delivery: Challenges, prospects and lessons. Commonwealth Journal of Local Governance (7), 135-142.

Slack, L. (2014) The post-2015 Global Agenda - a role for local government. Commonwealth Journal of Local Governance, (15), 173-177. https://doi.org/10.5130/cjlg.v0i0.4069

Stroh, M. (2000) Qualitative interviewing. In: Burton, D. (ed.) Research training for social sciences: A handbook for postgraduate researchers (pp. 196-217). London: Sage Publications. https://doi.org/10.4135/9780857028051.d23

United Nations Development Programme. (UNDP) (2010) Botswana Millennium Development Goals: Status report 2010. Gaborone. UNDP Botswana Country office. Available at: www.bw.undp.org/content/dam/botswana/docs/Publications/Botswana\%202010\%20MDGs\%20Progress $\% 20$ Report.pdf

United Nations Development Programme. (UNDP) (2013) Botswana MDG acceleration compact - improving maternal health. Gaborone: UNDP Botswana Country Office.

United Nations Development Programme. (UNDP) (2014) High-level global dialogue on localising the post2015 development agenda. UNDP and the UN Human Settlement Programme (UN-Habitat). Available at: www.undp.org/content/dam/ecuador/docs/pnud_Ec_torino_Global Dialogue on Localizing the Post 2015 agenda.pdf

United Nations Development Programme. (UNDP) (2015a) Botswana: Millennium Development Goals status report 2015 - Sustaining progress to 2015 and beyond. Gaborone: UNDP.

United Nations Development Programme. (UNDP) (2015b) MDG overview. Gaborone: Botswana Country Office. Available at: www.bw.undp.org/content/botswana/en/home.html.html 
United Nations Development Programme. (UNDP) (2015c) Mainstreaming and linking poverty eradication, localisation and sustainable development considerations in the new national development vision for Botswana. Submitted to the National Strategy Office, Govt of Botswana. Gaborone: UNDP.

Vision 2036 Presidential Task Team. (2016) Vision 2036. Gaborone: Lentswe la Lesedi Publishers. Available at: http://statsbots.org.bw/sites/default/files/documents/Vision\%202036.pdf

World Bank. (2014) Botswana overview. Available at: www.worldbank.org/en/country/botswana/overview.

World Bank. (2017) World Bank country and lending groups: Country classification. Washington DC. Available at: https://datahelpdesk.worldbank.org [Accessed June 21, 2017].

Wright, C. (2015) Localising resources. Commonwealth Local Government Forum, CLGF SG blog. Available at www.clgf.org.uk/whats-new/clgf-blog/localising-resources 